\title{
Labor Injunctions in Action: A Five-Year Survey in Los Angeles County
}

\author{
Benjamin Aaron* and William Levint
}

HISTORICAL BACKGROUND OF INJUNCTIONS IN THE UNITED STATES

\section{Abuse and Reform}

At the 1924 convention of the California Federation of Labor, the first proposition submitted to the assembled delegates dealt with "The Injunction Evil." As drafted by its co-sponsor, Andrew Furuseth, it read in part as follows:

Whereas there is a fundamental difference between law and equity-law being the will of the people crystallized into statute by the people's representatives and signed by the executive of state or nation. Equity being the irresponsible will of a judge governed by his conscience, expressing itself through writs of injunction and enforced by fine or imprisonment by the same judge who has issued the forbidding order; ... therefore be it

Resolved ... that we denounce the use that is being made of the equity power under which the freedom of the individual and the government by law ... is being desecrated and a form of autocracy vested in the judiciary is being built up ....

Despite its faulty exposition of legal theory, this proposition accurately expressed the hatred and fear with which organized labor has always regarded the injunction in labor disputes. The explanation of labor's attitude toward injunctions is to be found in the dynamic, colorful, and frequently shocking history of the use of injunctions in industrial controversies. Although the Supreme Court of the United States had no occasion to pass upon the scope and validity of the labor injunction until 1895,2 the amazing rapidity with which this form of relief thereafter came to be relied upon by employers catapulted the issue into the national political arena.

But early attempts at legislative reform failed to achieve their purpose. Legislation designed to revise the substantive law of conspiracy and restraint of trade, as applied to labor unions, of which Section 6 of the Clayton Act of $1914^{3}$ was the most notable example, proved to be generally unsuccessful. The proponents of reform directed their efforts, therefore, toward limiting the equitable jurisdiction of the courts in labor disputes and toward correcting the procedural evils incident to the issuance and enforcement of labor injunctions. One of the earliest of these statutes was enacted in Cali-

* Research Associate, Institute of Industrial Relations, and Lecturer on Labor Law, Department of Economics, University of California, Los Angeles.

$\uparrow$ Research Assistant, Institute of Industrial Relations, University of California, Los Angeles.

1 Carifornta State Federation of Labor, Procezdnges of the Twenty-Fifte AnNust Convention 35-36 (1924).

2 In re Debs, 158 U.S. 564 (1895).

338 StAT. 730 (1914), 29 U.S.C. \$ 52 (1946). 
fornia in 1903.: This law legalized combinations to engage in acts in furtherance of labor disputes, and also prohibited the issuance of "any restraining order; or injunction ... with relation thereto." Nevertheless, in the first case testing the law, the Supreme Court of California sustained an injunction which enjoined picketing in a labor dispute. 5

On the federal level, Section 20 of the Clayton Act $^{\circ}$ purported to limit drastically the power of the federal judiciary to issue restraining orders and injunctions in labor disputes. This proved not to be the case, however; for the Supreme Court of the United States subsequently ruled that the statute introduced no new principle into the equity jurisprudence of the courts, but was "merely declaratory of what was the best practice always."

As injunctions came to be utilized by employers with increasing frequency in the ensuing years, criticism of the scope of these injunctions and of the manner in which they were obtained and enforced also multiplied. Labor unionists were not alone in their opposition, but were joined by many others who deplored the decisive role played by the courts in labor disputes. In 1923 Federal Judge Amidon penned his classic indictment of the more objectionable practices then being followed in the issuance of injunctions; 8 but it remained for several of the country's outstanding scholars to make the exhaustive analyses of the uses and abuses of labor injunctions which, coupled with a growing popular revulsion against current judicial practices, ultimately resulted in legislative reform. Two books-The Labor Injunction, by Frankfurter and Greene, and The Government in Labor Disputes, by E. E. Witte-are the landmarks in this field; and their authors participated in the drafting of the Norris-La Guardia Act, ${ }^{9}$ adopted by Congress in 1932. By 1941, 17 states had passed laws modeled after the federal statute..$^{10}$

These authorities considered the following as chief bases for complaint against the injunctive process, as it then operated in labor disputes: ${ }^{11}$

1. The courts have refused to recognize that breaches of the peace may be redressed through criminal prosecutions and civil actions for damages.

2. They have expanded a simple judicial device into an enveloping code of prohibited conduct, absorbing en masse executive and police functions.

3. Issuance of restraining orders and preliminary injunctions in labor disputes cannot preserve the status quo; "irreparable damage" may

4 CaI. Stat. 1903, c. 235.

5 Goldberg, Bowen and Co. v. Stablemen's Union, 149 Cal. 429, 86 Pac. 806 (1906); accord, Pierce v. Stablemen's Union, 156 Cal. 70, 103 Pac. 324 (1909).

638 SraT. 730 (1914), 29 U. S. C. $\$ 52$ (1946).

7 American Steel Foundries v. Tri-City Central Trades Council, 257 U. S. 184, 203 (1921).

- 8 Great Northern Ry. v. Brosseau, 286 Fed. 414 (D. N. Dak. 1923).

947 Stat. 70 (1932), 29 U.S.C. §§ 101-115 (1946).

10 Millis and Montgomery, Organized Labor 647 (1945).

11 Frankfurter and Greene, ThF Labor Injunction 199-205 (1930); Witte, Tire GovERNMAENT IN LABOR DISPUTES 83-133 (1932). 
result to a union from the issuance of an injunction designed to protect an employer from similar loss.

4. Courts cannot find facts quickly and fairly by replying solely upon the complaint and the affidavits of interested or professional witnesses.

5. The legal doctrines in labor injunction cases are illusory and ambiguous, and must usually be applied by a judge unfamiliar with them.

In considering proposed reforms, these authorities emphasized primarily the establishment of procedural safeguards. They urged that legislatures determine, first, whether judge-made law governing employer-employee "competition" conforms to prevailing concepts of public policy; and second, the desirable extent of those changes deemed necessary. Finally, they agreed that only within very narrow limits is it the function of courts to apply their own notions of policy. ${ }^{12}$

\section{Revival of Interest}

Since 1932 there has been no investigation of the injunctive process in labor disputes comparable to those of Frankfurter and Greene and of Witte. In a sense, this lack of continuing interest is a measure of the effectiveness of federal and state anti-injunction legislation in curbing abuses of the labor mjunction. With the passage of the Taft-Hartley Act, ${ }^{13}$ interest in the use of the labor injunction revived; for although this statute does not restore the injunctive remedy to private parties, ${ }^{14}$ it does make substantial encroachments upon the area previously protected by the Norris-La Guardia Act. ${ }^{15}$

Labor representatives also fear that recent pronouncenients by the Supreme Court of the United States on the right of state courts to limit union activity may cause a resurgence in the use of labor injunctions in those states which, like California, have no anti-injunction statutes. ${ }^{16}$ The Court held, in a group of cases decided last year ${ }^{17}$ that picketing aimed at securing an objective contrary to the public policy of the state, as determined by either its courts or its legislature, may be restrained without violating the constitutional guarantee of freedom of speech, unless the balance struck by the state between the constitutional right to communicate ideas and the conflicting public policy is "inconsistent with the rooted traditions of a free people."18

12 Frankfurter and Greene, op. cit. supra note 11, at 205-228; WitTe, op. cit. supra note 11 , at $298-302$.

1361 StaT. 136 (1947), 29 U.S. C. \$\$141-167 (Supp. 1950).

14. Amazon Cotton Mill Co. v. Textile Workers Union of America, 167 F.2d 183 (4th Cir. 1948) ; Gerry v. Superior Court, 32 Cal. 2d 119, 194 P. $2 d 689$ (1948); Int'1 Longshoremen's \& Warehousemen's Union v. Sunset Line and Twine Co., 77 F. Supp. 119 (N. D. Cal. 1948).

15 See $\$ \S 10(j)$ and $10(1)$ of Title I, and $\$ 208$ of Title II.

16 See, e.g., Zeeman v. Amalgamated Retail and Department Store Employees, $17 \mathrm{CCH}$ LAB. Cas. $\llbracket 65,572$ (L. A. Super. Ct. 1950), in which the court, reversing an earlier ruling approving home picketing, and relying upon recent United States Supreme Court decisions (note 17 infra), declared the state policy to be against such picketing.

it Hughes v. Superior Court, 339 U.S. 460 (1950); Int'l. Brotherhood of Teamsters v. Hanke, 339 U. S. 470 (1950); Building Service Employees v. Gazzam, 339 U. S. 532 (1950).

18 Int'l. Brotherhood of Teamsters v. Hanke, 339 U.S. 470, 479 (1950). 
This article is an outgrowth of a study undertaken by the Institute of Industrial Relations, University of California at Los Angeles, at the request of the Subcommittee on Labor-Managenient Relations of the United States Senate Committee on Labor and Public Welfare. ${ }^{19}$ The purpose of the study was to ascertain the extent to which labor injunctions are now being issued in selected areas throughout the country; the practices and procedures commonly followed in this type of case; and the effects of labor injunctions upon the rights and interests of the parties involved. The scope of the present article is limited: it covers only Los Angeles County for the period from January, 1946 to July, 1950. It is hoped, however, that the findings and conclusions may have a significance extending beyond their immediate focus. In the following discussion the findings and recommendations of the authorities previously mentioned will be subjected to detailed re-examination in the light of the facts disclosed by the Los Angeles County study, in order to determine the extent to which the conclusions of the earlier studies have been confirmed or modified by recent conditions. ${ }^{20}$,

\section{FINDINGS}

\section{Number and Types of Labor Injunctions and Procedures Governing Their} Issuance and Enforcement

Number of Complaints Filed. Approximately 65 to 70 applications for injunctive relief in labor cases have been filed each year during the period surveyed. The sole exception was 1947, in which only 37 cases of this type were found. (Figures for the first half of 1950 (31) indicate that the total for that year probably reached 60 or more cases.) There is, of course, no such thing as a "normal year" in the field of labor-management relations; but in attempting to account for the low number of cases in 1947, the writers have found it more meaningful to explain the larger number of cases in the other three and one-half years.

Labor disputes increased generally throughout the country in 1946, and the Los Angeles area was no exception. This increase was attributable to many causes, but the principal and virtually universal cause was the strong reaction of both management and labor to the removal of numerous restraints imposed during World War II. Another important factor in Cali-

10 Other institutions participating in this study were the New York State School of Industrial and Labor Relations, Cornell University; the University of Wisconsin; and Duke University.

20 The procedure followed in the Los Angeles County survey was as follows: A list of the 265 cases surveyed (better than 90 percent of the total number occurring during the period in question) was obtained from the files of Department 34 of the Superior Court of Los Angeles County. Time permitted a thorough examination of the files in only 151 of the 265 cases. A cross-section of the cases was studied including most of those ultimately appealed. Not all of the information about the labor injunction cases was obtained from an examination of the court files. In order to determine how these disputes were finally settled, and why, interviews were obtained with some 30 men prominently associated with labor-management relations in Los Angeles. Among the men interviewed were consultants and attorneys representing management, labor attorneys and union officials, a representative of the Metropohtan Police Department, a member of the legal stafi of the NLRB, and several judges of the superior court who lave presided in Department 34. 
fornia was the so-called "Hot Cargo" act, ${ }^{21}$ which prohibited secondary boycotts and secondary picketing. Many injunctions were sought by employers under this statute until it was declared unconstitutional by the state supreme court in 1947.:- In 1948 the number of injunction cases in the Los Angeles area was boosted appreciably by the attempt on the part of the International Ladies Garment Workers Union (AFL) to organize a number of small garment manufacturing establishments. And in 1949 a continuing fight between the Teamsters and the Retail Clerks was responsible for an increase in injunction cases. Another dispute in the cleaning and dyeing industry, involving both the AFL and the CIO, also increased the number of injunction suits in 1949.

Complainants in Injunction Cases. While the labor injunction has been utilized chiefly by employers, there is evidence that labor has undergone a considerable change in attitude toward the propriety of the use of that weapon in disputes with employers and between unions. In the period between 1892 and 1932 Professor Witte found 91 cases of injunctions sought by, or in behalf of, labor unions against employers or public officials. In the period, 1930-1932, these instances were one-fourth as numerous as the applications for injunctions by employers. ${ }^{23}$ The study of Los Angeles County shows that in 30 out of 265 cases a labor union was the complainant, with another union or an employer as defendant. An additional 17 suits resulted from intra-union disputes.

The majority of labor injunction suits, however, are still brought by employers. In the Los Angeles study 201 of the 265 cases fell in this category. ${ }^{24} \mathrm{~A}$ check was made of 120 of these employer-complainant cases; it revealed, among other things, that injunctions are most frequently, although not exclusively, sought, within the employer group, by establishments employing less than 100 employees.

Several factors explain why small employers apply for injunctive relief more frequently than do large businesses. First, the former generally employs no labor relations counsel; he usually refers labor matters to the same attorney who handles his other legal affairs. The attorney frequently is inexperienced in labor relations matters and tends to regard an injunction as the only feasible method of dealing with this novel and disturbing situation. ${ }^{25} \mathrm{~A}$ second factor is union tactics. Some unions have on occasion attempted to organize the employer, rather than his employees. This is especially likely to arouse the employer's, and possibly the employees', resentment and opposition. Certain types of small businesses are particularly vulnerable to sudden union strike action. The grocery store proprietor,

21 CAL. LABOR CODE \$\$ 1131-1136 (1941), a wartime measure, was made permanent in CAL. LABOR CODE $\$ \S 1131-1136$ (1947).

22 In re Blaney, 30 Cal. 2d 643, 184 P.2d 892 (1947).

23 WrTrE, op. cit. supra note 11, at 231-234.

2t Twenty-five of 201 suits filed by employers allegedly arose out of jurisdictional disputes. In addition to 201 employer suits and 47 union cases, 17 miscellaneous suits were brought by individuals or by companies in some capacity other than that of employers.

25: This theory is supported by the fact that in 120 employer suits 47 attorneys appeared in one case only. whereas only six appeared in as many as four cases. 
dealing largely in perishables, needs quick relief; so it is natural for him to think first of an injunction.

The fact that the employer-complainant in an injunction suit has only a few employees does not always tell the whole story. In recent years, more and more employers, particularly those in smaller businesses, have combined to form employer associations which retain labor relations consultants whose services would probably be beyond the reach of individual employers. Some injunction suits are part of an industry-wide policy. For example, in tracing the outcome in a suit filed by a retail establishment, the writers were told by the employer's attorney that he was unable to supply any' information about the background of the dispute or its ultimate outcome. He was simply told to file suit, on the basis of the advice given his client by the trade association's labor relations consultant.

Types of Conduct Sought to be Enjoined. Efforts to classify the 120 employer suits according to conduct complained of proved generally unsatisfactory. The difficulty of drawing a meaningful distinction between "illegal purposes" and "illegal means" in these cases is too well recognized to require further explanation. Moreover, many complaints were drawn by lawyers obviously inexperienced in labor relations law who apparently felt that the best tactic was to make sweeping charges of illegal conduct. Further, it was often impossible to determine which of the conflicting statements made by the litigants were true.

A substantial majority of labor injunction suits brought by employers against unions are based primarily upon alleged violence on the picket line. Such was the claim in 73 out of 120 employer suits. Other types of union conduct complained of included violations of California's "Hot Cargo" and Jurisdictional Disputes ${ }^{26}$ Acts, unfair competition and restraint of trade, and breaches of collective bargaining agreements.

In the Los Angeles area, most internal union disputes resulting in litigation have grown out of conflicting jurisdictional claims by rival unions. Impetus to the growing tendency of unions to take legal action against their rivals was given by the recent expulsion from the CIO of the left-wing unions. The CIO organization in California was, until a short time ago, under the control of the "left-wingers" and their expulsion from CIO ranks has naturally resulted in some litigation over union property and membership rights. A wholly different reason may be the expanding role which attorneys have played in the conduct of union affairs in recent years.

Nature of Complaints and Answers. On the basis of his extensive research, spanning over 40 years, Professor Witte concluded, in 1932, that complaints and answers in labor injunction cases are thoroughly standardized. As he described them, ${ }^{2 \pi}$ the complaints begin with a recital of the property holdings and the nature of the business of the complainants, followed by a description of the defendants. Next comes an allegation that the defendants have conspired to injure complainants. Buttressing this is a recital

26 CAL. LABOR CODE $\$ \$ 1115-1120$.

2i WitTe, op. cit. supra note 11 , at $86-87$. 
of the strike, if any, and of all the clashes between strikers and strike breakers, which are represented as having been instigated in furtherance of the unlawful conspiracy. Any instances of actual violence are set forth in detail; but if no violence has occurred, "coercion," "threats," and "intimidation" are alleged in general terms. These allegations are followed by a claim that the defendants will continue their unlawful activities unless restrained and that the complainants will suffer irreparable injury. The complaint concludes with a prayer for relief, usually including a precise statement of the terms of the injunction sought.

The answer generally contradicts all material averments set forth in the complaint. The defendants deny, pro forma, that they have conspired to injure the complainants; frequently they retaliate by charging that the complainants have conspired to destroy the union. The answer concludes with a request for dismissal of the suit, and is sometimes accompanied by a cross-complaint and a prayer for an injunction against the complainants.

Generally, these descriptions apply to the cases in Los Angeles County investigated by the writers. According to labor spokesmen, some management attorneys, having no experience in the labor field, model their complaints after earlier successful ones. The results were characterized as products of careful draftsmanship, rather than of careful investigation of the facts. There is some truth in these contentions. A casual perusal of a few dozen of the complaints filed in labor injunctions suits is sufficient to indicate that many are modeled after those in earlier cases; in some instances they are phrased in identical language.

On the other hand, the answers filed by unions also appear to conform to the pattern described above. Sometimes these sweeping denials boomerang. A local attorney called the writers' attention to one case, involving organizational picketing, in which the employer expected no relief other than a limitation upon the number of pickets. The defendants filed only a general denial, unsupported by affidavits, denying "each and every allegation" in the complaint. The court enjoined all picketing, reasoning that if it was being carried on, the defendants were lying; while if they were indeed telling the truth, they could not reasonably object to the injunction.

Use of Affdavits. Complaints and answers are almost invariably accompanied by supporting affidavits. Determination of important questions of fact on the basis of affidavits, in lieu of the testimony given by witnesses in open court, has long been a principal target of criticism, not only by labor leaders, but by all disinterested observers. Nevertheless, the standard procedure of Department $34^{2 \mathrm{Ta}}$ is to rule on petitions for temporary restraining orders or preliminary injunctions solely on the basis of affidavits. In only one of 151 cases were witnesses heard at this stage of the proceedings. Detailed affidavits are customarily offered the court by employers and, to a somewhat lesser extent, by unions. In recent years employers have made increasing use of photographs to support charges of illegal conduct. While it is impossible for the writers to determine the degree of truth in these

2ra See note 20 supra. 
affidavits, ample reason exists for questioning the credibility of some. A few examples will suffice. In one case, the complainant submitted 10 affidavits executed by various employees, all cast in identical language. In another, the complainant stated that he had no foreknowledge of a strike; yet he filed his complaint within two hours after the strike began.

The court is not, however, simply faced with a problem of determining, by affidavits, which side is telling the truth. Often it must decide whose version of the same incident best describes the picture. In one suit, for example, the complainant's affidavit alleged that union pickets had stopped a freight truck making a delivery to the plant, and had "refused to allow it to enter." In describing the same incident, the union's affidavit stated that the truck driver had simply been advised that a strike was in effect, whereupon he "said he would not cross the picket line."

While opposition to the presentation of facts by affidavit in injunction cases comes chiefly from unions, no one interviewed preferred such a procedure to the hearing of witnesses in open court. One judge, however, asserted that he generally could obtain a fairly clear and accurate picture of the facts in any injunction case after studying the affidavits and hearing the oral arguments of counsel. Another judge, conceding the obvious difficulty in evaluating affidavits, argued that this difficulty is not peculiar to labor injunction cases, but is inherent in any proceeding involving the use of sworn statements.

In any event, the procedure followed in Department 34 is dictated by necessity rather than adopted by choice. The fact is that there is not sufficient time to hear witnesses. About 150 cases are heard in the Department each week; the hearing of witnesses would slow up the court's work intolerably.

Extensive depositions might compensate, to some degree, for the weaknesses of the presentation of facts by affidavits. Unfortunately, obtaining depositions is costly and time-consuming; and consequently they are seldom used.

Temporary Restraining Orders. Applications for injunctions almost invariably include a prayer for a temporary restraining order prohibiting the defendants from engaging in any of the acts complained of until the case can be heard. The issuance of teniporary restraining orders is discretionary with the court. Theoretically, such orders are granted only to prevent irreparable injury; ${ }^{28}$ but the frequency with which they are issued in Los Angeles County indicates that "irreparable injury" is given so broad a definition as to render the distinction between it and less serious damage virtually meaningless. A few figures tell the story. In 120 suits filed by employers, a temporary restraining order was requested in 114 and granted in 103. Each of the 11 cases in which the temporary restraining order was denied involved, primarily, a question of law. In not a single case was such relief denied an employer who based his complaint upon alleged acts of violence.

${ }^{28}$ Cac. Code CIv. Proc. \$ 526(2). 
One of the most objectionable features of temporary restraining orders is that they are frequently $c x$ parte. The Norris-La Guardia Act and similar state laws have virtually eliminated such orders within their respective spheres, but the practice still flourishes in some jurisdictions. The judges in Department 34 continue to grant ex parte temporary restraining orders. In recent years, however, they have adopted a practice designed to give unions a chance to present their side of the controversies before the temporary restraining orders are granted. Thus, if a union attorney writes a letter to Department 34, requesting notification of the filing of an anticipated suit against his client, the clerk will attempt to notify him before any order is issued. No accurate figures are available regarding the instances in which union attorneys have received advance notice of requests for injunctions; but one judge estimates that union attorneys were consulted by the court in about 50 percent of the cases against larger unions before any action was taken.

Some management attorneys declare that they make it a regular practice, before asking the court for injunctive relief, to notify the union's attorney. This policy is predicated, they explained, not so much upon notions of fair play and due process as upon a desire to protect themselves. As one management attorney put it, "If no union representative goes into the judge's chambers with you, the court will tend to argue the union's side." Yet there are certain dangers, from the employer's point of view, in notifying the union in advance. One management attorney cited instances in which certain union officials, upon receipt of advance notice, immediately left town to avoid service. Union attorneys differ in their evaluations of these informal conferences. Some insist that "it is all a waste of time; the judge will sign whatever is put in front of him." Others assert that conferences prior to the issuance of a temporary restraining order have resulted in more reasonable orders.

The very nature of $c x$ parte proceedings strongly suggests that temporary restraining orders, which are almost invariably prepared by the complainant's attorney, ${ }^{20}$ are frequently unjustified, or at least are too broad in their terms. Professor Witte found 120 cases in 24 jurisdictions in which temporary restraining orders were either dissolved or materially modified after a hearing. ${ }^{30}$ The cases included in the instant survey, however, indicate a contrary result. An analysis of the 103 cases in which employers obtained temporary restraining orders shows that subsequent modification of these orders was so slight as to constitute only a negiigible factor. Thus, during the 10-day statutory time limit between the granting of the temporary order and the hearing on the order to show cause why a preliminary injunction should not issue, union attorneys involved were able on only two occasions to convince the court that the temporary restraining order was improper or unfair. In two other instances the temporary restraining order

2" The preliminary injunction is more likely to be a product of the joint efforts of opposing counsel, based upon oral rulings from the bench. The judge may, however, completely rewrite any proposed order.

30 WITTE, op. cit. supro note 11 , at 335-340. 
was modified, but in both of these cases the modification came, not during the 10-day period, but while hearings were being held on the preliminary injunction.

The same general pattern is reflected in the 52 cases in which both a temporary restraining order and a preliminary injunction were granted. In 24 of these cases the preliminary injunction was the same as the temporary restraining order; in three cases the preliminary injunction was the same as the modified temporary restraining order. The preliminary injunction differed from the temporary restraining order in 25 of the 52 cases.

All of these temporary restraining orders were based upon affidavits, and over half of them were issued ex parte. Thus, even in those cases in which union attorneys had no opportunity to present counter-affidavits or oral argument prior to the issuance of the temporary restraining order, they were unable, for the most part, subsequently to demonstrate that the order was improper in its original form. Indeed, in many instances in which the temporary restraining order has been modified, greater, rather than fewer, restrictions have been placed on union activity.

Preliminary Hearings and Temporary Injunctions. California law provides for a 10-day mandatory limit between the granting of a temporary restraiming order and the hearing on the order to show cause why a preliminary injunction should not be granted. ${ }^{31}$ Sometimes the court will shorten the time period, particularly if it has denied the restraining order. If no hearing is held within 10 days, the delay will have been agreed to by the union attorneys.

This 10-day limitation does not mean that the court must make a ruling on the application for a preliminary injunction by the end of that period. Sometimes the hearings on a preliminary injunction stretch over days, or even weeks, because Department 34, with its crowded schedule, cannot devote too much of its time to any one case, and must try to hear difficult cases between times. If a particular case will tie up the court for too long, the presiding judge assigns it to another department of the court. But during these hearmgs, the court generally continues the temporary restraining order. Furthermore, after the hearings end, the court may require some time to study the legal issues. During this period, any temporary restraining order granted remains in effect. The judges have obviously made a definite effort to hand down memorandum decisions as soon as possible after conclusion of the hearings, usually within a week. Additional time, however, is sometimes taken. In one case, for example, the court took six weeks to decide that no preliminary injunction should issue and then dissolved the temporary restraining order.

No findings of facts are made by the court in labor injunction cases, nor does the court generally hear witnesses in the preliminary injunction proceedings. This was true in all but one of the cases studied.

In about half of the cases surveyed in which an employer sought injunctive relief the proceedings never passed beyond the stage of a temporary

31 Cax. Code Crv. Proc. $\$ 527$. 
restraining order. Thus, in the 120 employer-complainant suits, temporary restraining orders were granted in 103, and thereafter preliminary injunctions were sought in only 68 . In 56 of these 68 , the complainant obtained the additional relief. In a number of instances, however, although no preliminary injunction was issued, the temporary restraining order was continued by order of the court. This was generally the case when the union has filed no answer. ${ }^{32}$

The fact that preliminary injunctions are usually granted after both sides have been heard is cited by management attorneys to support their contention that they do not file a suit for equitable relief unless it will stand up under the degree of examination required before a preliminary, or even a permanent, injunction will be granted. On the other hand, labor attorneys discount the fact that the court so seldom changes its mind after having first considered the case on the basis of employer affidavits. One prominent labor attorney stated: "Despite all clains to the contrary, I am convinced that the granting of a temporary restraining order tends to cause the judge to sustain his original action when he rules on a preliminary injunction."

California law requires that a bond be given whenever a preliminary injunction is granted..$^{33}$ Although a bond need not be filed with applications for temporary restraining orders, ${ }^{34}$ the courts generally insist on this. The amounts of the bonds have been small, generally ranging from somewhere between $\$ 500$ and $\$ 1,000$ for temporary restraining orders, and going a bit higher for prelininary injunctions. The courts reason that a smaller bond is justified for a temporary restraining order, since that order is in effect for such a limited time, whereas the preliminary injunction may remain in effect indefinitely. The employers' bonds seem small compared to the unions' costs in sone cases. In no case examined, however, has the union moved against the bond, and the infornation gained fron the interviews indicates that this is true generally.

Several reasons are given for the unions' failure to move against the bonds. First, they must prove that the temporary order should not have been granted, and such proof is often inipossible or prohibitively expensive. Furthermore, damages suffered by the unions are difficult to show. The biggest item, generally, is attorneys' fees, and the law in this regard is that fees charged for opposing the action itself are not recoverable. Only that portion attributable to services rendered in producing dissolution of the injunction can be clainied..$^{35}$

Trials and Permanent Injunctions. Theoretically, temporary restraining orders and preliminary injunctions are intended to control the actions of the parties only until a full trial can be held, but the fact is that injunction

32 The union's failure to file an answer may be due to the fact tbat the employer's charges are true. But one union attorney told the writers that his experience in suits alleging violence has shown that "contesting the case by affidavits is practically a useless act."

33 CAL. CODE CIV. Proc. \$ 529.

34 Biasca v. Superior Court, 194 Cal. 366, 228 Pac. 861 (1924).

35 The rule is well expressed in Curtiss v. Bachman, 110 Cal. 433, 437, 42 Pac. 910, 911 (1895). 
cases almost never reach the trial stage. Out of 120 suits brought by employers, only four went to trial; in two cases the relief was granted.

Generally, a permanent injunction offers the employer no particular advantage. As one management attorney explained, "If an empoyer has a preliminary injunction that is being obeyed, he is not interested in getting a permanent injunction."

Some management attorneys argue that the union's reluctance to demand a trial after the court has granted a preliminary injunction is an indication that the injunction was properly issued. Union attorneys respond that a request for trial is rarely made because the case could almost never be heard until long after the dispute was settled, by which time the court's decision would have little or no practical effect.

Sometimes the dispute becomes deadlocked and continues for a considerable period of time. If the employer then seeks an injunction, the intervention of the court may prove decisive, despite its avowed purpose of merely preserving the status quo. A striking example of this is presented in Voeltz v. Bakery \& Confectionary International Union. ${ }^{36}$ On December 7, 1948 the union called a strike which was supported by 10 out of 49 employees. On November 19, 1949 the non-strikers, having formed an independent organization, demanded exclusive representation rights and threatened a strike of their own if the employer signed a contract with the defendant union. The employer then sought to have all picketing enjoined, arguing that he was now embroiled in a jurisdictional strike. The defendant union contended, in part, that the independent union was dominated by the employer. The trial judge decided that "it cannot be said, at this stage of the proceedings, that the employee organization is not free from company domination and control." Accordingly, the court ruled that there.was sufficient support for the employer's claim of a jurisdictional strike to entitle him to injunctive relief "until the case can be tried." The preliminary injunction, prohibiting the Bakery Workers from picketing the employer's plant, as well as from representing to any person that the employer or his product was unfair to organized labor, was issued on February 14, 1950.

The sequel to this case reveals both the strength and the weakness of labor injunctions. The trial court's decision was appealed by the Bakery Workers and, as of the date of this writing, is in a district court of appeal. In the meantime, the injunction continues in effect. Ordinarily, this would have meant a victory for the employer in practical terms, but, in this case the Teamsters have also been picketing the employer as a result of a dispute over the right to represent a group of driver-peddlers. The loss to the employer has been substantial. The Bakery Workers' strike continues, with their picketing being done for them, in effect, by the Teamsters.

Appcals. The decision of the trial court to grant or to deny a request for a preliminary or a permanent injunction may be appealed by either party. With respect to restraining orders, the procedure is for the defend-

3617 CCH LaB. Cas. $\{65,615$ (L. A. Super. Ct. 1950). 
ants to move for dissolution or modification; this brings the case on for a preliminary hearing.

Relatively few labor injunction cases are appealed. Of 120 employercomplaint suits, only five have been finally disposed of on appeal as of the date of this writing, although others are now pending. The small number of appeals is attributable to the same two factors which so vitally affect all other phases of this type of litigation: time and money. Appeals take months, or even years, ${ }^{37}$ and the parties in these cases want immediate action. The cost factor is also a controlling consideration in most cases; unions, as well as employers, are willing to appeal only those cases involving major legal issues.

When a union does decide to appeal, it sometimes adopts the dramatic method of directing one of its members to defy the injunction, thus raising the issue of the legality of the injunction in habeas corpus proceedings growing out of the conviction of that member for contempt. ${ }^{3 s}$ By this method the unions obtained rulings from the California Supreme Court on the constitutionality of the "Hot Cargo" Act, ${ }^{39}$ and on the jurisdiction of the state courts over unfair labor practices affecting interstate commerce. ${ }^{40}$

Scope and Content of Injunctions. The scope and content of temporary restraining orders, preliminary injunctions, and permanent injunctions are much alike. They invariably apply to the defendants, "their officers, agents, representatives, members, employees, pickets, attorneys and confederates." In addition, they usually apply to "all persons acting by, through, or in concert with" the defendants, and to "all persons acting in aid of or in conjunction with" them. While they do not contain the blanket clause, "all persons whomsoever," formerly employed in federal court injunctions, these orders are binding, nevertheless, upon all persons who, knowing of their issuance, aid or abet the named parties in violations. ${ }^{41}$

The writers have found no injunction to match in scope and content some of the more horrendous examples cited by Witte and by Frankfurter and Greene. It does appear, however, that the restraints in many of them are "couched in terminology of vague and profoundly controversial significance." 4" By way of illustration, one temporary restraining order enjoined those against whom it was directed, inter alia, from "imposing or threatening to impose any penalty upon, or causing or threatening to cause any damage to, any employer who purchases, handles, uses, transports or sells plaintiff's products." This provision would appear to prohibit eco-

$3 i$ See, for example, Dixon Boiler Works $v$. Int'l. Brotherhood of Boilermakers (L. A. Super. Ct. 1946), in which a preliminary injunction was granted on June 18, 1946. The decision of the California Supreme Court, dismissing the union's appeal, was handed down three years later, on March 30, 1949. 33 A. C. No. 21, p. 1 of Minutes.

as The California Supreme Court has ruled that "habeas corpus is an appropriate remedy to obtain ... release ... from confinement pursuant to a conviction of contempt based on violation of the void order." In re De Silva, 33 Cal. 2d 76, 79, 199 P. 2d 6, 8 (1948).

39 In re Blaney, 30 Cal. 2d 643, 184 P. 2 d 892 (1947).

40 In re De Silva, 33 Cal. 2d 76, 199 P. $2 d 6$ (1948).

\pm 1 Berger v. Superior Court, 175 Cal. 719, 167 Pac. 143 (1917).

4 FR.iN KFURTER AND Gresive, op. cit. supra note 11 , at 97 . 
nomic pressure by the defendants against any persons dealing with the plaintiff, even in the case of an entirely separate controvers:

The injunctions are customarily rather lengthy and. in some respects. quite detailed in their use of language. Restraints against picketing also usually forbid "standing," "sitting," "loitering." "gathering." "assembling." "marching." "parading." "walking." "stopping," or "stationing, placing, or maintaining any pickets at the place of." Those against violence prohibit "intimidating," "coercing," "threatening," "molesting," "pushing," "elbowing," "shouldering," and the catch-all, "otherwise physically contacting the person or clothing of." Other restrictions upon pichet-line conduct include prohibitions against "lewd or boisterous talk or shouting or yelling."

Opinions differed on how detailed the court orders should be. One labor attorney characterized an ideal order as "concise, direct, specific, so that the actual workingman, when he reads one of these documents, understands what he is prohibited from doing." A management attorney blames labor, at least partially, for the complex character of the injunctions. He explained:

Originally, we made the orders simple. The pickets then proceeded to ignore the orders. When we had them cited for contempt, union attorneys would find some loophole in the injunction. In our next case, we would plug that loophole, and the union attorneys would find another. Sometimes we used to argue for days on the wording of a preliminary injunction. And the orders got longer and longer. Furthermore, there are effective means other than picketing, such as the use of unfair lists and secondary boycotting, by which unions can exert their economic force. Getting at these conspiracies is another reason for the detailed nature of the orders.

In court orders directed against violence, the portion to which the unions usually object most strongly is the limitation placed on the number of pickets. The superior court in Los Angeles has made it practically a rule that in any case in which it finds there has been some violence it will limit picketing to one to three pickets at each entrance to the employer's place of business, the pickets to maintain a specified separation of from 10 to 20 feet. The court does not take into account the number of workers on strike; and it generally applies the same standards to businesses located in populous sectors of the city and to those lying in the outskirts. ${ }^{43}$ Similarly, the court does not differentiate between small and large places of business, except that the number of entrances and exits govern the number of pickets. The court thus appears to have taken the unions" argument that "picketing is only a means of advertising the dispute" at its face value, and has concluded that only a few pickets are needed for this purpose. ${ }^{4 \pm}$

43 See, however, Lewis v. ILGWU, 14 CCH LAB. Cas. $\llbracket 64,454$ (L. A. Super. Ct. 1948), in which the court pointed out that "the number of pickets permissible in any one area is not a criterion for another area where the types of business and the use made of the sidewalks vary materially."

44 Thus in the Lewis case, the court said: "If a union wishes to publicize its strength, a statement on a placard carried by a single picket can advertise the union's numerical strength as well, it would seem, if not better, than by a show of numbers on the picket line." Ibid. 
Methods of Enforcement. Injunctions are enforced by contempt proceedings, and the penalties for contempt may be severe. Traditional union hostility to injunctions is based, in part, upon the complex, technical, and ambiguous character of the court orders, and also upon the system which permits the judge, sitting without a jury, to hear the cases of those accused of violating the injunction which he has issued.

In the Los Angeles area, however, the problem of contempt is not a serious one. Of 151 cases, only 12 led to contempt citations. All but one were instituted by employers; the sole exception was an inter-union action. Five were dismissed before trial. In three of the remaining actions the judge who issued the original order also presided at the trial for contempt. Convictions resulted in all three cases, but two of these were reversed on appeal. In the third case the defendant pleaded guilty. The trial of the remaining four was presided over by a different judge than the one who granted the injunction. Two resulted in convictions and two in acquittals.

Proceedings for criminal contempt may be brought by the City Attorney under Section 166.4 of the State Penal Code making it a misdemeanor to violate a court order. An aggrieved party may also institute proceedings for civil contempt. Technically, once a person has been cited for contempt, further proceedings are in the hands of the court, and only the judge can dismiss the charge. As a practical matter, however, the burden of carrying these citations to trial rests exclusively upon the complaining party. In most of the labor injunction cases, the primary aim of the complaining party is to settle the dispute; and as a union attorney pointed out, "Unless the employer succeeds in getting the contempt proceedings dropped, he will have a great deal of difficulty in reaching a settlement with the union." As a consequence, if the employer and the union reach a settlement, terms include an agreement by the employer to drop the contempt proceedings.

Some dissatisfaction with this practice has been voiced by judges and by management attorneys. Such settlements, it is argued, reflect a cynical attitude toward the court and toward individuals whose rights have been violated. In the 1948 oil strike, one of the oil companies and the union filed a stipulation with the court, agreeing among other things that, with the court's permission, a number of contempt citations would be dismissed. The company's attorney was severely reprimanded by the court for filing this stipulation. Nevertheless, that same day the order to show cause regarding contempt was discharged.

This willingness to approve the private settlements of litigants is sometines difficult to reconcile with the solemn warnings against violation of its decrees occasionally issued by the superior court. For example, in granting a preliminary injunction, the court in one case warned: "that any individual, whether he is or is not connected with a labor organization, will do well not to violate any order of the Superior Court." 45

In other cases, however, the court has taken a nore tolerant view of minor violations of injunctive orders, which are proportionally much greater

${ }^{45}$ Lewis v. ILGWU, 14 CCH LAB. CAs. $\llbracket 64,454$ (L. A. Super. Ct. 1948). 
than the instances of serious defiance. In one such case the court, after noting that the alleged violations of the injunction "partook of form rather than substance," stated:

For these reasons ... The Court is of the opinion that justice and harmony among the employers and the union employees involved herein will best be served and preserved by granting this motion to dismiss, leaving all parties to withdraw from the controversy with honor. ${ }^{46}$

The relatively few contempt proceedings can be credited to several factors; but most important is the fact that unions and their members generally abey the terms of the orders.

Management attorneys cite as another reason for the infrequency of contempt proceedings the fact that contempt convictions are so difficult to obtain. The accused must be found, beyond a reasonable doubt, to have violated the injunction, and this is extremely difficult to prove. Management attorneys also point out that an educational process is preferable to litigation, particularly if there has been only a slight violation of the order. Finally, they are well aware of the fact that nothing arouses union membership so much as jailing someone for contempt. This is particularly inportant in cases in which the employer and the union have an established collective bargaining relationship and must continue to live together after settlement of the present dispute.

Nevertheless, it would be wrong to underestimate the effect on union conduct due to the threat of contempt proceedings. One management attorney pointed out that, "so far as cutting down violence is concerned, even citing someone for contempt has a favorable effect. The word spreads around, and the pickets act more cautiously."

Union people, though they admittedly no longer worry too much about possible contempt proceedings, emphasize that such proceedings can hurt the unions financially. Furthernore, they point out that contempt citations and actual proceedings can seriously harass the union and greatly lessen its chances of victory. ${ }^{47}$

Actions for Damages. Most complaints filed by employers in injunction cases also included a prayer for damages. The amounts claimed ranged widely; and only a few attorneys made a serious effort to evaluate the employer's losses as a result of the alleged illegal action of the union. In none of 151 cases, however, were any damages awarded.

The main reason for this failure to collect damages is that generally a settlement is reached; and that settlement usually calls for the dismissal of all pending court actions. The same considerations which lead employers to drop contempt proceedings also influence their decision to dismiss damage suits.

46 Union Oil Co. v. Oil Workers Int'l. Union, 16 CCH Lab. CAS. \65,049 (L. A. Super. Ct. 1949).

17 The writers have been advised that during the oil strike of 1948 there were 60 contempt citations pending against the union president which could have subjected him to over $\$ 30,000$ in fines and 300 days in jail. 
A somewhat less important deterrent to the collection of damages is the fact that the damages are so difficult to prove. Although some of the union's conduct may be tortious, much of it is legal; and it is no simple matter to determine which activity caused the damage. Also, as a management attorney pointed out. one of the best ways of proving damages - that of bringing in customers to show loss of trade-is generally not utilized because this "might embarrass such customers and posibly have a harmful effect on their relationships with their employees."

A few of the management attorneys insisted that they "mean business" in damages claims. As one expressed it, "The fact that we haven't pushed damages in the past is no sign we won't the next time." But even if management does not fear the effect of damage suits on its labor relations and even if it can offer real proof of damages, it faces the problem of getting a jury to force a union to pay large sums to a business enterprise. All of these factors make it likely that management will continue to sue for large sums in damages and then do little or nothing to collect them.

Rolc of Police. Historically, the police have played a vital role in labormanagement disputes which have resulted in picketing and strikes. In the past, unions have felt, with a great deal of justification, ${ }^{48}$ that management used the services of the police to break strikes and to "bust" unions. But the picture has changed in recent years, and the position of the police is now more neutral than formerly.

A police department representative has outlined the department's policy with respect to labor disputes as follows:

When we learn that a strike is imminent, we contact responsible union officers and outline to them the department's position with regard to this labor controversy: advising them that we represent the public and that we expect them to conduct their picket lines in conformance with the law. We tell them that if they have anyone on the picket line whom they can't control, they should put them off. We go to the management people and tell them a similar story before the strike develops. We warn them that they can't buy meals for the officers, can't give them anything, can't fraternize with them, and can't get any information from then. We tell the officers themselves what the score is. They are told not to discuss the issues with anybody.

We do not put officers to work watching the picket lines if only a reasonable number of pickets are being used, unless there are complaints of violence. We consider a reasonable number of pickets to be about two or three at each entrance.

Unions like to hold what they call demonstrations for a short period of time-about a half hour or so. They generally like to hold these demontrations at the time men are going in and out of the plant, at which time the unions bring in a lot of members and engage in mass picketing. Union leaders will notify us in case they plan such a demonstration and ask us to send officers "just in case" someone gets out of line. We've handled numerous cases like this and have never had any trouble.

${ }^{48}$ See, e.g., Sex. Rep. No. 398, Part 2, 78th Cong., 1st Sess. 997-1015 (1943). 
If there is violence, the police will make arrests under established lawgenerally assault and battery ordinances-and not as a violation of a court order. Pohice are as willing to make arrests for acts of violence before a court has issued an order as after. They will arrest anyone they see violating the law; a court order makes no difference.

Whether the police are successful in carrying out this policy is a matter of some disagreement among unions and employers. Surprisingly enough, in view of the historical background, the most strenuous objections to police conduct come from management. Some say that the police will make no arrests for violence, particularly before the court issues an injunction, unless the violence is especially flagrant. Union representatives, on the other hand, contend that police make so few arrests for violence simply because so little violence has been committed.

Some judges of the superior court have publicly indicated that they incline toward management's point of view on this issue. In one case, involving mass picketing, the court criticized the conduct of the police as follows:

The officers of the city, whose duty it is and was to enforce the law ... knew such picketing was in violation of the law. Surely the administrative officers of the city need not await the injunctive processes of the courts to prod thein into doing that which should be done without court intervention. ${ }^{49}$

In making arrests the police face a real problem. The day after a strike ends, the people who were formerly at war with each other are back working side by side. The police have found in these instances that even if arrests have been made, the complaining witnesses are reluctant to testify. They can be forced to testify, but generally will not give strong evidence. To avoid this, the police try to have the complaining party make a "citizen arrest," after which the officer on duty will take the accused party to the station. Then, if the injured party wants to withdraw charges, he can do so; but if he elects to press charges, he will be more likely to tell the whole truth in court.

Criminal proceedings for alleged violations of injunctions are occasionally instituted by the police. ${ }^{50}$ No conviction on these charges can be obtained without proof that the pickets have been informed of the order; therefore, the order is read over a loud speaker and policemen are posted at each end of the picket line, so that they can testify to having heard it. Simultaneously, police take photographs of the picket lines. The pickets are then given a "reasonable time to disperse" before any arrests are made.

Generally, the police department is reluctant to initiate contempt proceedings. Before taking any action to enforce an injunction, the department's practice is to consult with the city attorney as to the validity of the order. The complaining party would naturally prefer that the police make

49 Lewis v. IIGWU, 14 CCH LAB. CAS. If 64,454 (L. A. Super. Ct. 1948).

50 In the Hollywood film strike of 1946, Metropolitan Police arrested over 600 pickets for such violations. All but a few were found guilty and were either fined or sentenced to jail terms. 
the arrests; but in line with its policy of not enforcing injunctions of doubtful validity, the department sometimes refuses requests from management attorneys to take such action.

"Clean Hands" Doctrine. Unions in the Los Angeles area have had no success in using as a defense against accusations of violence the countercharge that the employer has come into equity with "unclean hands." Though unions have quite often accused employers of such tactics as firing union leaders, refusing to arbitrate, or making illegal threats, the courts have refused to deny injunctions on those grounds. In $U$. S. Electrical Motors v. United Electrical, Radio and Machine Workers of America, the court stated:

A refusal to bargain further with employees or their union representative does not justify or render immune unlawful acts of the employees committed in picketing in a subsequent strike ....51

\section{The Effects of Injunctions in Labor Disputes}

Injunctions and Acts of Violence. The man in the street is inclined to think of injunctions as a means of preserving law and order. As Professor Witte remarks, "There is a widespread belief that, but for injunctions, violence and bloodshed would be much more frequent than they now are." 52 Employers incline to hesitate to rely upon the more drastic and permanent sanctions of the criminal law in cases of alleged violence. The police, despite the statements to the contrary, may be less willing to curtail illegal conduct on the picket line before an injunction is issued than afterward. This is the view of most management attorneys and some judges. On the other hand, in some cases the alleged violence may be exaggerated and not sufficient to sustain a conviction..$^{53}$ This view is frequently expressed by labor attorneys.

Injunctions and Non-Violent Conduct. While some injunctions are aimed at an alleged illegal purpose of the defendant union, most are designed merely to regnlate the union's conduct during the course of the dispute. Ever since the decision of the Supreme Court of the United States in American Steel Foundries v. Tri-City Central Trades Council, ${ }^{\text {,4 }}$ both federal and state courts have generally implemented their injunctions in labor disputes with relatively specific instructions relating to the number of pickets and the nature of their conduct. This procedure is followed in the Los Angeles area.

The effects of this limitation are most keenly felt in organizational strikes. Of 120 injunction suits brought by employers, 56 involved organizational attempts. The largest group of these cases grew out of the 1948 organizational drive of the International Ladies Garment Workers Union. Insistence by labor groups that injunctive relief given the employer will

51166 P. 2d 921, 922 (L. A. Super. Ct. 1946). Cf. \& 8 of the Norris-La Guardia Act, 47 SrAT. 72 (1932), 29 U.S. C. $\$ 108$ (1946).

52 WITTE, op. cit. supra note 11 , at 111.

53 According to Metropolitan Police records, only 140 arrests were made for violence in labor disputes in the period studied.

54257 U.S. 184 (1921). 
kill all chances of success in the organizational effort receives some support from the subsequent histories of these cases. In only 14 out of 56 was the union ultimately successful. Significantly, the most successful unions were those best able to apply secondary pressures against the employer.

There is no real argument about the effect of injunctions in an organizational dispute. All parties agree that injunctions have their inost damaging effect upon unions calling strikes not strongly backed by employees. But managenient and labor do have different stories to tell in discussing the justification for injunctions in these disputes.

Labor's point of view was expressed by one umion spokesman as follows:

The employer gets an injunction as soon as we start picketing. He gets the court to cut down on the number of pickets and to limit secondary activity of the union. The terms of the injunction are bad enough. But what really hurts is the effect of the court's order on the rank-and-file workers. No matter what the court says about only "maintaining the status quo," the fact of the matter is that the workers feel the court has "judged" the dispute and has come up with the verdict that the union is wrong. In an organizational dispute, where some of the workers go on strike, it's vitally important they be allowed to demonstrate their strength and their solidarity. And it's important that this strength and solidarity be demonstrated the first few days of a strike. But what happens, when the court issues an injunction, is that the workers who are on the borderline about joining-up see the one or two pickets parading in front of the gate and they think the strike's a flop; and they decide they'd better not indicate to the boss that they may be sympathetic to the union or they'll lose their job. As for the striking workers, it's a tough enough proposition convincing these guys their only cliance of getting anything out of the boss is to risk their jobs and go on strike. And then, to be allowed only a couple of pickets-that really kills the works.

\section{In rebuttal, a inanagement representative commented:}

This "picketing-is-free-speecll" busimess unions toss around is a lot of nonsense. They aren't dealing in terns of free speecls when they line up, 50 strong, in front of the plant. They aren't trying to "educate" the nonstriking workers to join the union; they're simply trying to scare them into joining. All the court order does is limit picketing and enjoin acts of violence. What are the unions kicking about? The court is only telling them not to do what they have no right to do anyhow. And if the unions really want to picket only as an expression of free speech, surely several pickets are enougli to do the trick.

Injunctions and Breaches of Contract. In 16 cases employers sought injunctions based upon alleged breaches of contract by unions. Fourteen of the agreements involved contained "no-strike" clauses. In some of these suits, the existence of the contract was in doubt; in others, it was not clear that any breach had occurred; and the remainder presented clear-cut evidence of violation of the collective bargaining agreement by the union. 
Even the protection of an injunction has not always persuaded the employer firmly to resist union pressure and to refuse to grant concessions. One managenient lawyer had this to say about such a case:

The strike was settled when the company made some sort of minor wage concessions, either by agreeing to a new arbitration or a modification of the existing arbitration agreement. The company was wrong in yielding, and I am convinced the injunction was 100 percent effective and could have forced the union to abide by the agreenent.

In the "breach-of-contract" cases, orders are nore diversified than those issued in violence cases. In determining the legal effects of "no-strike" clauses, courts are limited by the well-established equitable principle that contracts for personal service will not be specifically enforced. The court orders are ainied, therefore, at union leaders and their activities. In one clear-cut violation of a closed-shop collective bargaining agreement, the union had ordered its nien off the job because of alleged "incentive" nuethods set up by the employer. The court enjoined union officials from causing, instituting, permitting, encouraging, or ordering the workers to strike; intimidating or threatening any members of defendant union or any other person who undertook to work for plaintiff; taking any disciplinary action against those working at plaintiff's project; inducing stoppage of supplies to plaintiffs; and notifying any person that a strike existed at plaintiff's project; and also directed umon officials to notify nembers to cease their strike and to return to work. The order specifically stated, however, that it should not be construed as requiring individual workmen to return to work.

A provision which prohibits the union from taking any disciplinary action against members who go back to work is particularly effective in many instances. The consequences of expulsion from the union upon continued employment have, of course, been ameliorated by relevant provisions of the Taft-Hartley Act; ${ }^{55}$ but the threat of expulsion or of heavy fines is bound to have a strong effect upon individual union members. Court orders of this kind, however, raise very serious questions with respect to judicial interference with the union's freedonl of action in the conduct of its internal affairs.

Injunctions and Restraint of Trade. A recent decision indicates that injunctions are potent weapons in cases arising out of alleged restraints of trade by unions. In 1949 the Amalgamated Meat Cutters and Butcher Workmen and the leading grocery stores in Los Angeles negotiated, and were preparing to execute, an agreement containing a provision that none of the merchandise under the union's jurisdiction could be sold on nights, Sundays, and holidays, when the butchers were not working. The net effect of the provision would have been to cut drastically the sale of frozen meat, fish, and poultry products, or possibly to eliminate them altogether.

At that stage Kold Kist, Inc., one of the frozen neat packers, filed an action in the superior court, alleging that the union and the grocery stores were violating the Cartwright Act. ${ }^{66}$ The superior court enjoined the de-

5561 STaT: 140, 141 (1947), 29 U.S. C. $\$ 158$ (a) (3) and (b) (2) (Supp. 1950).

56 CAL. Bus. AND PROF. CODE $§ \S 16720-16758$. 
fendants from executing any agreement including the proposed provision. ${ }^{\mathbf{5 7}}$ A district court of appeal upheld the superior court, ${ }^{58}$ and the California Supreme Court refused to hear the case on appeal. In its opinion the district court ruled that the result of the proposed scheme would be to restrain trade illegally. Answering the union's contention that the sole purpose of the provision was to regulate hours of employment, the court held that there was "no true relation between the stated objective and the means proposed to be used to accomplish it." ${ }^{59}$ As a result, butchers in most markets now work Sundays, holidays, and evenings.

Injunctions and the NLRB. The Taft-Hartley Act makes it an unfair labor practice for a labor organization or its agent to restrain or coerce employees in the exercise of the rights guaranteed to them under the Act, or employers in the selection of their collective bargaining representatives. ${ }^{60}$ Despite this fact, charges that unions have committed such unfair practices are only infrequently filed with the Los Angeles regional office of the NLRB. About a dozen of such charges which were filed against unions in the past year went as far as some preliminary investigation; of these, only one or two reached the hearing stage. Since the processes of the board are far too slow to provide effective relief, an employer, faced with coercive tactics by the union, prefers going to the state courts for an injunction. ${ }^{61}$

The NLRB has recently given notice, however, that it feels in no way bound by a state court decision that a union picket has engaged in violence. In Standard Oil Company of California, ${ }^{62}$ the employer sought to defend itself against the union's unfair labor practice charges that it had fired a number of strikers for union activity by citing the conviction of some of these men for violation of a court injunction against violence. The board dismissed this argument principally on the ground that it was not bound by a proceeding to which it had not been a party.

Under the Taft-Hartley Act, a jurisdictional strike is defined as one in which the union is seeking to compel the employer to assigu to its own members work tasks being performed by others. ${ }^{63}$ But California's Jurisdictional Disputes Act appears to be much broader in scope. The possible effect of the California statute upon rights of employees under the federal law is indicated in a recent case, still pending before the NLRB, in which a union contract protected by a state court injunction from interference by a rival union is also the subject of an unfair labor practice charge.

\section{CONCLUDING REMARISS}

The study has produced clear evidence that injunctions are still frequently obtained in the Los Angeles area, although whether the courts play

57 Kold Kist, Inc. v. Amal. Meat Cutters and Butcher Workmen of N. A., 16 CCH LAB. CAs. โf 65,111 (L. A. Super. Ct. 1949).

ts 99 A. C. A. 226, 221 P. $2 d 724$ (1950).

5099 A. C. A. 226, 233, 221 P.2d 724, 729 (1950).

6061 STAT. 141 (1947), 29 U. S. C. \$ 158(b)(1) (Supp. 1950).

01 Another explanation is that many employers in the area are, or claim to be, outside the coverage of the NLRA. In their case the state courts provide the only appropriate forum.

6\% 91 N.L. R. B. No. 87 (1950).

G3 61 STAT. 142 (1947), 29 U. S. C. $\$ 158$ (b) (4)(D) (Supp. 1950). 
as prominent a role in labor disputes as they did 15 or 20 years ago is doubtful. Any diminution in this role, however, cannot be attributed to a growing conviction of the courts that the injunctive remedy is inappropriate in most labor disputes. If the number of labor injunctions has decreased, the explanation will be found in the changing attitudes of parties whose outlook on industrial relations problems has gradually matured over the intervening years.

Most injunctions today are requested by small employers, and many result from union organizational attempts. Unions have little luck in their organizational efforts once an injunction has been granted; but whether this lack of success can be traced solely to the court's interference, or to the inadequate efforts of the union to sell the merits of unionization to the employees in question, is not always clear. All unions know, and some will admit, that a degree of intimidation is often a vital ingredient in a successful organizational drive.

The fact that judicial attitudes on this point have not greatly altered is evidenced by the ease with which injunctive relief can still be obtained. This is particularly true if the employer alleges that union pickets have committed violence. The predisposition on the part of judges to find that sufficient violence has occurred to justify limitations upon picketing is due largely to the prevailing attitude that an injunction against violence merely prohibits the union from doing what it has no right to do. ${ }^{64}$

It seems apparent that the courts still give insufficient recognition to the fact that breaches of the peace may be redressed through criminal prosecutions and civil actions for damages. The study revealed a divergence of opinion with respect to the diligence of the police in preventing disorder on the picket line prior to the issuance of an injunction. Whatever the true facts may be in this regard, it is surely the counsel of wisdom that: "The enforcement of the law where the law is clear ... should not ... be transferred from the executive or administrative departments of the city to the judiciary." 65

The difficulties of prosecuting an action for damages to a successful conclusion cannot, of course, be ignored. Nevertheless, claims for damages are in most cases included in complaints merely to put added pressure on the union, and not with the intent of pressing such claims all the way. To be sure, there is nothing morally wrong with this; but because an employer elects not to seek relief against violence in an action for damages, he is not thereby automatically entitled to an injunction. While there are undoubtedly some circumstances involving violence in which an injunction is the only adequate remedy, there are also many others in which either criminal prosecutions or civil actions for damages, or a combination of the two, afford the employer ample protection and redress. With respect to damages it

\footnotetext{
64 In criticism of this interpretation, one management attorney has written that, "whereas many employers do not seek injunctive relief despite violence, none seek such relief unless violence is actually occurring to a degree justifying relief."

65 Lewis v. ILGWV, supra note 49.
} 
should be noted that both the state ${ }^{66}$ and the federal ${ }^{67}$ laws permit damage suits to be brought against a union in its own name. Moreover, those unions strong enough to inflict serious harm upon employers, whether by violent or peaceful means, are usually in sound financial condition.

Assuming the need for equitable relief in some situations, it would seem that many injunctions are too broad in scope and lend some justification to the criticism that courts have expanded "a simple, judicial device to an enveloping code of prohibited conduct." ${ }^{6 s}$ The courts in the Los Angeles area customarily regulate picket-line activities with extreme particularity, and the restrictions in soine of these orders seem somewhat unrealistic to the extent that they attempt to specify such conduct as gestures and tone of voice. Picket lines cannot be expected to be conducted with "the decorum of a college debate." 69

In addition to the argument that detailed injunctions are occasioned by attempts by strikers and others to evade the commands of court orders cast in more general terms, it is also frequently pointed out that even detailed injunctions are often flouted by pickets, or at least are not strictly enforced. If this is true, however, then a question arises as to the wisdom of a practice which must inevitably lead to a disrespect for judicial processes. ${ }^{\text {T0 }}$

This study also bears out earlier findings that injunctions cannot preserve the status quo in situations as dynannic as labor disputes. At least half of the suits do not get beyond the stage at which a temporary restraining order is issued; only a very few ever go to trial. Labor disputes are generally won or lost during the first few days after the picketing or boycotting begins, and what the court may decide weeks or months later is usually of little concern to the parties. Intervention of the court on the side of the employer provides him with a powerful psychological weapon, and the critical importance of the original rulings is indicated by the fact that only a handful of such cases are appealed.

In terms of procedure, the judges in this area follow, for the most part, the same practices in labor injunction cases which in the past have been the target of so much criticism. No witnesses are heard in hearings on applications for preliminary injunctions; no findings of fact are made; and many of the temporary restraming orders are ex parte in character. To the extent that it has followed the practice of consulting with opposing counsel before issuing temporary restraining orders, the local court has, in recent years, made commendable progress toward a more equitable procedure; but it would appear that considerably more could be accomplished in this regard. Only five union attorneys represented the defendants in over half of the 120 suits filed by employers, and it would seem that such a small group could easily be given notice and the opportunity to be heard prior to

60 Cat. Code Crv. Proc. $\$ 388$; see Comment, 33 Carm. L. Rev. 444 (1945).

6761 Stat. 156 (1947), 29 U.S. C. $\$ 185$ (Supp. 1950).

68 Fr.ankfurter and GreENe, op. cit. supra note 11, at 200.

60 Hellerstein, Picketing Legislation and the Courts, 10 N. C. L. REv. 158, 183 (1931).

70 There is some evidence, however, that unions try to take advantage of both sides of this argument. See, for example, Union Oil Co. v. Oil Workers Int'l. Union, 15 CCH LaB. CAs. II 64,870 (L. A. Super. Ct. 194S). 
the issuance of any temporary restraining order against one of their clients.

If the decisions in any individual cases have been unsound, the cause is likely to be found in the "illusory and ambiguous" 11 legal doctrines applied, rather than in the conduct of the judge. The difficulty and complexity of the problems raised in the initial stages of labor cases has been expressed by Judge Hanson as follows:

While the courts have generally held it is permissible and proper to picket peacefully where the objective is ... lawful, opinions differ materially as to what is and what is not "peaceful picketiug" and a "lawful objective." The views of appellate courts on these subjects can hardly be said to be crystal clear. Accordingly when a trial court judge is called upon to issue an injunction in a labor controversy he is faced not only with the problem of stating what may not be done, but to state it in language that is comprehensive and yet clear. But this, as is well known, is not easily done. ${ }^{72}$

In this classic understatement is revealed the magnitude of the problem confronting trial judges in labor controversies.

Police conduct in dealing with labor disputes today represents a considerable improvement over that of earlier years. Police officials now appear to have a much greater sense of responsibility for mamtaining a neutral attitude in labor controversies. This awareness can be traced, at least partially, to the emergence of organized labor as a major political influence in the last 10 years.

Some criticism comes fronl representatives of both labor and management, as well as from the judiciary, regarding the handling of contempt cases. One management attorney suggested that a party seeking a citation for contempt be required to file a bond. A union attorney contended that contempt of injunctions is a public offense and as such "ought to be prosecuted, if at all, by public authorities." Such a procedure, he argued, would discourage frivolous charges and would insure thorougli investigation of any case in which a citation was ultimately issued. On the whole, however, all parties seem willing to continue the current practice in the handling of contempt charges.

The evidence produced by this study of the general effectiveness of labor injunctions can hardly be deened conclusive. In some instances, notably organizational strikes, injunctions are usually the decisive factor in the eniployer's favor; at least for the short run. On the other hand, strong unions cannot be defeated in the pursuit of their objectives by injunctions alone. One labor union spokesman holds that injunctions tend generally to hurt unions more in good times than in bad. He reasons that when jobs are plentiful, employees prefer to leave an employer with whom they are in a dispute rather than to undergo the hardships of a prolonged fight; but in depression periods they frequently have no alternative but to stay.

The ineffectiveness of injunctions is particularly noticeable in inter-

TI FRANKFURTER AND GREENE, op. cit. sulpra note 11, at 202.

72 Union Oil Co. v. Oil Workers Int'. Union, supra note 70. 
union disputes. In such cases, despite court intervention in favor of the weaker side, the stronger union almost invariably wins out.

As previously noted, labor injunctions are fairly easy to obtain in this jurisdiction; yet relatively few entployers have taken advantage of the opportunity to secure them. Indeed, inost management representatives have indicated that they regard a labor injunction as the last and the most undesirable of the various alternatives available to an employer. The conclusion seems inescapable, therefore, that the injunction is not so effective a remedy as many uninformed persons believe, and that the residue of ill feeling which remains long after the injunction has been dissolved may limit its effectiveness still further. Considering the high financial cost of the injunction, together with its adverse psychological effect, it is not surprising that nore experienced practitioners would prefer to find other ineans for the settlement of labor disputes.

No one familiar with the manner in which industrial disputes are conducted today can deny that an injunction is the only appropriate remedy in certain situations. These situations, however, are relatively rare. The "injunction evil," to the extent that it may still be said to exist, lies in the routime application of an extraordinary remedy to ordinary cases. In the last analysis, no better advice concerning the use of injunctions in labor disputes can be found than that given by Chief Justice Taft: "Injunctions in labor disputes are merely the emergency brakes for rare use and in case of sudden danger." 73 